\title{
STUDY ON IN VITRO TOXICITY OF BIOMETAL(II) MONENSINATES AGAINST RAT ZAJDELA LIVER TUMOUR
}

\begin{abstract}
The ability of Monensic acid A $\left(\mathrm{MonH} \cdot \mathrm{H}_{2} \mathrm{O}\right)$ and its neutral metal complexes $\left[\mathrm{M}(\mathrm{Mon})_{2}\left(\mathrm{H}_{2} \mathrm{O}\right)_{2}\right]$ with ions of $\mathrm{Mg}^{2+}, \mathrm{Ca}^{2+}, \mathrm{Mn}^{2+}, \mathrm{Co}^{2+}, \mathrm{Ni}^{2+}$ and $\mathrm{Zn}^{2+}$ to decrease viability and proliferation of primary cell cultures, originating from a chemically induced transplantable liver tumour of Zajdela in rats, and bone marrow cells from the same tumour-bearers, was evaluated. Experimental data revealed that manganese(II) and nickel(II) complexes of Monensin A are relatively more selective against the tumour as compared to the healthy bone marrow cells.
\end{abstract}

Keywords: chemically-induced rat tumour of Zajdela, bone marrow cells, Monensin A biometal(II) complexes, cytotoxic/antiproliferative effect

\section{Introduction}

Monensin, a well-known natural polyether ionophore (PI), is a coccidiostatic and antibacterial agent with wide application in stock farming [1-15]. Monensin is a mixture of four analogues, A, B, C and D, which are produced by Streptomyces cynnamonensis, with Monensin A being the major component (98\%). Nowadays the main form of Monensin, commercially available and used in livestock production, is its sodium salt.

In the last decade it was shown that this drug possessed significant antitumour activity (mainly in micromolar range) against malignancies as leukemia, lymphoma, myeloma, renal cell carcinoma, cancers of the colon, breast, cervix, etc. The antibiotic (applied alone or in combination with other therapeutics) was found to decrease the viability and proliferation of cancer cell lines via various mechanistic modes of action.

Thus, Park et al. determined that ligand induces a G1 and/or a G2-M phase arrest in human lymphoma, renal cell carcinoma, human myeloma, and colon cancer cells by decreasing both the activity of CDK-2 and CDK-6 associated kinases, and the levels of cyclin A, cyclin B1, cyclin D1 and cyclin E proteins. In some cases apoptotic process of

\footnotetext{
${ }^{1}$ Institute of Experimental Morphology, Pathology and Anthropology with Museum, Bulgarian Academy of Sciences, Acad. G. Bonchev 25, 1113 Sofia, Bulgaria, email: rialexandrova@ hotmail.com

${ }^{2}$ Institute of Neurobiology, Bulgarian Academy of Sciences, Acad. G. Bonchev 23, 1113 Sofia, Bulgaria

${ }^{3}$ Department of Analytical Chemistry, Faculty of Chemistry and Pharmacy, Sofia University "St. Kliment Ohridski”, J. Bourchier Blvd. 1, 1164 Sofia, Bulgaria, email: ipancheva@chem.uni-sofia.bg

${ }^{4}$ Biovet Ltd., Research and Development Department, 4550 Peshtera, Bulgaria, email: p_dorkov@biovet.com

*Corresponding author: ipancheva@chem.uni-sofia.bg
} 
cancer cells was associated with the changes of Bcl-2, Bcl-XL, caspase-9, caspase-3, and caspase-7 proteins as well as mitochondria transmembrane potential $(\Delta \Psi \mathrm{m})$ loss [16-19].

Later Ketola et al. and Kim et al. reported on the ability of Monensin to elevate intracellular oxidative stress in prostate cancer cells by increasing the generation of intracellular reactive oxygen species and by induction of a transcriptional profile characteristic of an oxidative stress response [20-22]. The observed effects were potentiated by combinatorial treatment with antiandrogens and antagonized by antioxidant vitamin $\mathrm{C}$.

In 2011-2013 Tyagi's group performed an extensive research on human epidermoid carcinoma $(\mathrm{KB})$ cells using various liposomal formulations containing ricin, Monensin and their combinations [23-25]. The researchers found that the liposomes can be used as in vivo deliver vehicles for the antibiotic to potentiate the cytotoxicity of liposomal ricin to eliminate KB cells.

Monensin is able to sensitize various glioma cells to TRAIL-mediated apoptosis, but not normal astrocytes, inducing endoplasmic reticulum stress, CHOP-mediated DR5 upregulation and proteasome-mediated downregulation of c-FLIP [26]. Furthermore, the drug potentiate the effect of rapamycin or erlotinib in lung cancer cells increasing the levels of proapoptotic proteins (bax, cleaved caspase 3, and cleaved poly(ADP-ribose) polymerase), and decreasing the anti-apoptotic proteins as bcl-2 and bcl-xL [27].

Tumova et al. reported that the polyether ionophore inhibits canonical Wnt signaling in human colorectal cancer cells and suppresses tumour growth in multiple intestinal neoplasia mice [28].

Monensin inhibits cell proliferation, migration and cell cycle progression, and induces apoptosis of ovarian cancer cells via suppression of multiple cancer-related pathways including Elk1/SRF, AP1, NFאB and STAT, and reduction of EGFR expression. The drug acts synergistically with EGFR inhibitors and oxaliplatin [29].

Very recently it was found that antibiotic induces cell death by autophagy and inhibits matrix metalloproteinase 7 (MMP7) in renal cell carcinoma [30], suppresses numerous cancer-associated pathways such as E2F/DP1, STAT1/2, NFkB, AP-1, Elk-1/SRF, and represses EGFR expression in chemo-resistant pancreatic cancer cell lines [31], promotes the final differentiation of melanoma stem cells and inhibits their stemness maintenance [32], as well as rapidly induces swelling of Golgi apparatus and perturbs mitochondrial function at the epithelial-to-mesenchymal transition (EMT) state [33].

Looking to the chemical structure of Monensic acid A $\left(\mathrm{MonH} \cdot \mathrm{H}_{2} \mathrm{O}\right.$, Fig. 1), it has to be recognized as a potential ligand able to bind metal cations. Indeed, this antibiotic is known as a monovalent polyether ionophore since it readily coordinates alkali metal ions as neutral complex species and transfers them through microorganism's cell membranes, disturbing metal homeostasis and leading to their death.

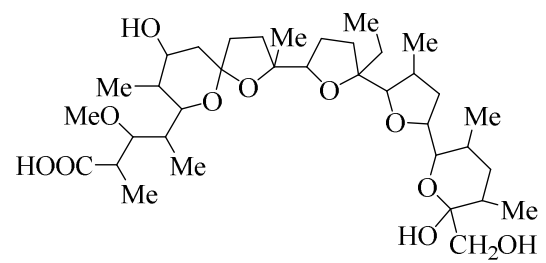

Fig. 1. Chemical structure of Monensic acid A 
Extensive studies on coordination chemistry of PI had proved that Monensic acid A binds also divalent biometal ions, forming complexes of composition $\left[\mathrm{M}(\mathrm{Mon})_{2}\left(\mathrm{H}_{2} \mathrm{O}\right)_{2}\right]$ [34-36]. In our studies on therapeutic properties of these new metal-based derivatives, we observed that they exhibit antitumor activity against cultured human permanent cell lines established from glioblastoma multiform, cancers of lung, breast, uterine cervix, and liver, as well as against virus-induced transplantable tumours in chicken (hepatoma) and in rat (sarcoma). In most cases the inclusion of biometal(II) ions into the structure of the polyether ionophore enhances significantly its ability to decrease the viability and proliferation of the treated cells $[37,38]$.

Well known in veterinary medicine for its efficiency against bacterial and parasitic diseases, Monensin attracts the attention of scientists with its promising antitumour activity. However, before being repurposed to oncology, its antineoplastic potential needs to be investigated in a wide range of model systems, and information on its toxicity to non-tumour cells must be obtained [39].

In the present paper we report our recent findings on in vitro biological efficacy of MonH and its complexes $\left[\mathrm{M}(\mathrm{Mon})_{2}\left(\mathrm{H}_{2} \mathrm{O}\right)_{2}\right]\left(\mathrm{M}=\mathrm{Mg}^{2+}, \mathrm{Ca}^{2+}, \mathrm{Mn}^{2+}, \mathrm{Co}^{2+}, \mathrm{Ni}^{2+}\right.$ and $\mathrm{Zn}^{2+}$, Fig. 2) using primary cell cultures established from Zajdela's tumour (chemically-induced liver cancer in rat) and bone marrow cells, isolated from the same tumour-bearing animals, as target cell lines.

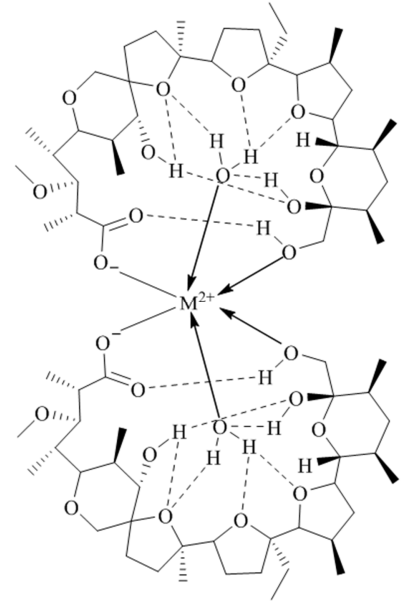

Fig. 2. Structure of mononuclear divalent biometal complexes of Monensic acid A [34-36]

\section{Materials and methods}

\section{Chemicals}

The commercially available sodium form of Monensin A (MonNa) was purchased from Biovet Ltd. (Bulgaria). Metal(II) salts and solvents were purchased from Riedel de Häen AG (Germany). Monensic acid A and metal(II) complexes were prepared as earlier reported [34-36]. Dulbecco's modified Eagle's medium (D-MEM) and fetal bovine serum were purchased from Gibco-Invitrogen (UK). Dimethyl sulfoxide (DMSO) was obtained from AppliChem (Germany); purified agar (Difco) and trypan blue dye were from SigmaAldrich Chemie GmbH (Germany). All other chemicals of the highest purity were 
purchased from local agents and distributors. All sterile plastic ware was from Orange Scientific (Belgium).

\section{Experimental animals, tumour and bone marrow cells}

Male Wistar rats (weighed 80-100 g, 2 months old) were purchased from Animal Center Slivnitsa (Bulgaria). Animals were given standard pellet diet and tap water ad libitum. All experiments with laboratory animals, included in the present study, were conducted in accordance with the requirements of the European Convention for the protection of vertebrate animals used for experimental and other scientific purposes.

The tumour of Zajdela, a chemically induced liver cancer in rat, was maintained as ascites tumour by intraperitoneal injection of viable, trypan blue dye excluded, tumour cells $\left(20 \times 10^{6} /\right.$ rat $)$. Primary cultures from the transplantable Zajdela's tumour were generated by isolation and washing in phosphate-buffered saline $(\mathrm{pH}=7.2,10 \mathrm{~min}$ ) of ascites cells from tumour-bearing animals. Femurs from euthanized Zajdela's tumour-bearing Wistar rats were dissected out, freed of connective tissue and muscle with gauze. Each bone was cut in half with scissors and the marrow was flushed out with D-MEM media using a syringe and a $26 \mathrm{G}$ needle. The cell suspension (pooled from both femur bones of each animal) was washed three times by centrifugation at $200 \times g$ for $10 \mathrm{~min}$.

\section{Cytotoxicity assay}

Bone marrow and Zajdela's tumour cells were seeded in 24-well plates in D-MEM (supplemented with 5-10\% fetal bovine serum, $100 \mathrm{U} / \mathrm{cm}^{3}$ penicillin and $100 \mu \mathrm{g} / \mathrm{cm}^{3}$ streptomycin) containing different concentrations of the compounds tested. Non-treated cells served as controls. The cell number and viability were determined after $72 \mathrm{~h}$ by trypan blue dye exclusion method using cell counter (Invitrogen ${ }^{\mathrm{TM}}$, Countess ${ }^{\mathrm{TM}}$, Automated Cell Counter).

\section{Results and discussion}

In the present study we have demonstrated for the first time that Monensic acid A and its biometal(II) complexes decrease significantly viability and proliferation of cultured cells isolated from a chemically-induced liver tumours of Zajdela in rat. In order to clarify better the cytotoxicity profile and selectivity of the compounds investigated we examined their activity also in healthy bone marrow cells (BMCs) obtained from the same tumour-bearing animals. Such model system represents the situation of cancer patients receiving chemotherapy. It is well known that due to the high proliferation rate and lack or very low expression of the MDR1 gene (ABCB1 gene coding for P-glycoprotein) usually the bone narrow cells also suffer during chemotherapy.

Ascitic Zajdela's cancer cells and BMCs from the same tumour-bearing rats were treated for $72 \mathrm{~h}$ with $\mathrm{MonH}$ and its complexes applied at concentrations of 5 and $10 \mu \mathrm{g} / \mathrm{cm}^{3}$, respectively. The influence of compounds on cell viability and/or proliferation was assessed by trypan blue dye exclusion method. Experimental data are presented on Figure 3; activity of MonH and corresponding complexes was compared at equimolar concentration of $7 \mu \mathrm{M}$. 


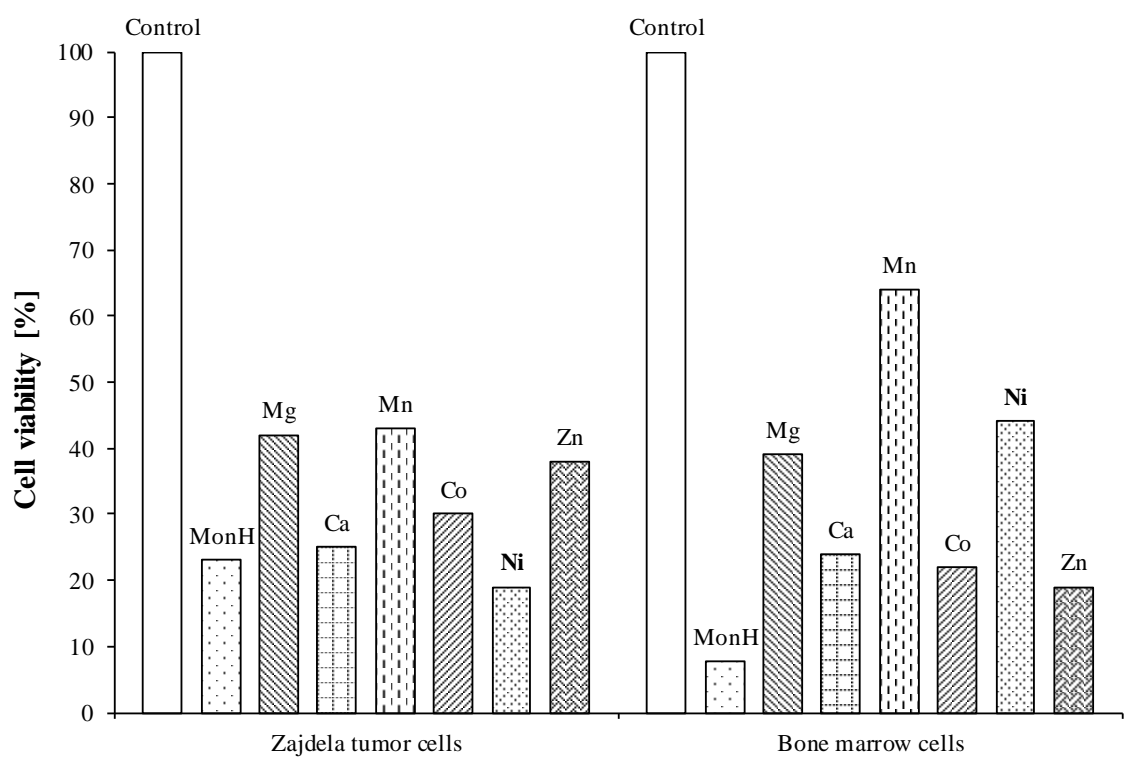

Cell culture

Fig. 3. Cell viability of Zajdela's tumour and bone marrow cells after $72 \mathrm{~h}$ treatment with MonH and biometal(II) complexes applied at concentration of $7 \mu \mathrm{M}$

Experimental results had shown that Zajdela's tumour cells are less sensitive to the toxic effects of MonH and its complexes with $\mathrm{Co}^{2+}$ and $\mathrm{Zn}^{2+}$ ions than bone marrow cells isolated from the same tumour-bearing animals. Coordination compounds of $\mathrm{Ca}^{2+}$ and $\mathrm{Mg}^{2+}$ ions possess similar toxicity in both cell types, while $\left[\mathrm{Mn}(\mathrm{Mon})_{2}\left(\mathrm{H}_{2} \mathrm{O}\right)_{2}\right]$ and $\left[\mathrm{Ni}(\mathrm{Mon})_{2}\left(\mathrm{H}_{2} \mathrm{O}\right)_{2}\right]$ exert higher activity against tumour cells as compared to the healthy BMCs cells. Other authors also reported no Monensin toxicity in non-tumour cells. For example, the ionophore antibiotic suppresses the proliferation of murine acute myeloid leukemia cells and intestinal tumours but is not harmful for healthy hematopoietic progenitors and normal mucosa, respectively [28, 40]. In addition, Monensin is toxic for human melanoma cells, but not for non-tumour human cells [32].

Based on the number of viable cells after $72 \mathrm{~h}$ treatment with the compounds tested, the following hierarchical orders of decreasing toxicity can be constructed for the polyether ionophore and corresponding metal-based derivatives:

Zajdela's tumour: $\mathrm{Ni}^{2+}>\mathrm{MonH} \sim \mathrm{Ca}^{2+}>\mathrm{Co}^{2+}>\mathrm{Zn}^{2+}>\mathrm{Mg}^{2+}>\mathrm{Mn}^{2+}$;

BMC: $\mathrm{MonH}>\mathrm{Zn}^{2+} \sim \mathrm{Co}^{2+} \sim \mathrm{Ca}^{2+}>\mathrm{Mg}^{2+} \sim \mathrm{Ni}^{2+}>\mathrm{Mn}^{2+}$.

Different sensitivity of Zajdela's tumour cells and BMCs can be explained at least partially by the following reasons:

i) It is well known that myelo-suppression is one of the main side effects of cancer chemotherapy. This fact is not surprising because conventional antineoplastic agents used in current oncology practice recognize and attack tumour cells due to their high proliferative potential. Bone marrow cells also possess high proliferative potential that makes them "visible" for the antitumour drugs. In addition, BMCs are characterized by 
low expression/lack of expression of MDR1 (ABCB1) gene encoding for transmembrane P-glycoprotein, which functions as efflux transporter pumping xenobiotics out of the cell [41].

ii) Cancer cells are characterized by high mutational instability - as a result, during carcinogenesis and tumour progression, cancer cells acquire genetic and epigenetic changes that facilitate their adaptation to environmental conditions, makes them more aggressive and increases their ability to survive under unfavourable pressures including chemical changes in their environment [42].

Monensin has been reported to effectively inhibit proliferation and migration of tumour cells and induce cell death by apoptosis and/or autophagy. The mechanism of its antineoplastic activity is not fully clarified yet but there are data confirming the ability of this agent to induce changes in $\mathrm{pH}$ and ATP content, to suppress expression and activity of matrix metalloproteinases (MMP-7) and to down-regulate various cancer-associated signalling pathways [16-33, 43, 44]. It is completely possible that some of these mechanisms could be also responsible for the cytotoxic/antiproliferative activities of its complexes with divalent biometal ions.

Repurposing of medications that are approved for application in other indications for use in oncology is one of the most promising modern strategies for treating cancer, as it saves time, money and effort. Undoubtedly, the antitumor activity of Monensin and its biometal derivatives, which has been demonstrated in a wide variety of cell cultures and animal models, including drug-resistant cancer cells, deserves special attention [31, 39, 45]. However, for this to occur, a number of conditions need to be met, including: i) its antitumor potential to be confirmed in various experimental models, adequately reproducing the biology and behaviour of tumours in vivo and predicting their response to Monensin exposure; ii) elucidation of its potential toxicity to healthy cells; iii) selection of the most appropriate form of administration of the drug or its derivatives/metal complexes, alone or in combination with other antitumour agents, etc.

\section{Conclusion}

In summary, the present study demonstrates that Monensic acid $\mathrm{A}\left(\mathrm{MonH} \cdot \mathrm{H}_{2} \mathrm{O}\right)$ and its biometal(II) complexes $\left[\mathrm{M}(\mathrm{Mon})_{2}\left(\mathrm{H}_{2} \mathrm{O}\right)_{2}\right]\left(\mathrm{M}=\mathrm{Mg}^{2+}, \mathrm{Ca}^{2+}, \mathrm{Mn}^{2+}, \mathrm{Co}^{2+}, \mathrm{Ni}^{2+}, \mathrm{Zn}^{2+}\right)$ exert cytotoxic and antiproliferative properties against animal cells obtained from chemically-induced liver tumour in rat. Although the bone marrow cells isolated from the same tumour-bearers are also sensitive to the treatment by the compounds studied, it was found that the presence of $\mathrm{Mn}^{2+}$ and $\mathrm{Ni}^{2+}$ ions enhances selectivity of Monensin towards tumour cells as compared to corresponding healthy bone marrow cells. Our findings contribute to a better elucidation of the potential antitumor properties and safety of Monensin and its biometal(II)-based derivatives.

\section{Acknowledgements}

This study was partially supported by Grants no. DFNI-B-02-30/2014 and no. KP-06-H29/3/2018 from the National Science Fund, Bulgarian Ministry of Education and Science. 


\section{References}

[1] Chapman HD, Barta JR, Blake D, Gruber A, Jenkins M, Smith NC, et al. Adv Parasitol. 2013;83:93-171. DOI: 10.1016/B978-0-12-407705-8.00002-1.

[2] Chapman HD, Jeffers TK, Williams RB. Poultry Sci. 2010;89:1788-801. DOI: 10.3382/ps.2010-00931.

[3] Anadón A, Martinez-Larrañaga MR, Castellano V. J Vet Pharmacology Therapeutics. 2009;32(S1):26-8. DOI: 10.1111/j.1365-2885.2009.01087.x.

[4] Stefańska J, Stepień K, Huczyński A, Tyski S. Polish J Microbiol. 2015;64:273-8. DOI: 10.5604/01.3001.0009.2122.

[5] Mimouni M, Khardli FZ, Warad I, Ahmad M, Mubarak MS, Sultana S, et al. J Mater Environ Sci. 2014;5(1):207-14. Available from: www.jmaterenvironsci.com/Document/vol5/vol5_N1/24-JMES-5622014-Mimouni.pdf.

[6] Rutkowski J, Brzezinski B. BioMed Res Int. 2013; art. 162513. DOI: 10.1155/2013/162513.

[7] Huczyński A, Stefańska J, Piśmienny M, Brzezinski B. J Mol Struct. 2013;1034:198-206. DOI: 10.1016/j.molstruc.2012.09.007.

[8] Huczyński A, Ratajczak-Sitarz M, Stefańska J, Katrusiak A, Brzezinski B, Bartl F. J Antbiot. 2011;64:249-56. DOI: 10.1038/ja.2010.167.

[9] Łowicki D, Huczyński A, Stefańska J, Brzezinski B. Tetrahedron. 2011;67:1468-78. DOI: 10.1016/j.tet.2010.12.033.

[10] Łowicki D, Huczyński A, Stefańska J, Brzezinski B. Eur J Med Chem. 2010;45:4050-7. DOI: 10.1016/j.ejmech.2010.05.064.

[11] Łowicki D, Huczyński A, Stefańska J, Brzezinski B. Tetrahedron. 2009;65:7730-40. DOI: 10.1016/j.tet.2009.06.077.

[12] Nelson ML, Grier MC, Barbaro SE, Ismail MY. Anti-Infect Agents Med Chem. 2009;8:3-16. DOI: 10.2174/187152109787047779.

[13] Hansen M, Krogh KA, Brandt A, Christensen JH, Halling-Sørensen B. Environ Pollut. 2009;157:474-80. DOI: 10.1016/j.envpol.2008.09.022.

[14] Kevin II DA, Meujo DAF, Hamann MT. Expert Opin Drug Discov. 2009;4:109-46. DOI: $10.1517 / 17460440802661443$.

[15] Huczyński A, Stefańska J, Przybylski P, Brzezinski B, Bartl F. Bioorg Med Chem Lett. 2008;18:2585-9. DOI: 10.1016/j.bmcl.2008.03.038.

[16] Park WH, Seol JG, Kim ES, Kang WK, Im YH, Jung CW, et al. Brit J Haem. 2002;119:400-7. DOI: 10.1046/j.1365-2141.2002.03834.x.

[17] Park WH, Jung CW, Park JO, Kim K, Kim WS, Im YH, et al. Int J Oncol. 2003;22:855-60. DOI: 10.3892/ijo.22.4.855

[18] Park WH, Kim ES, Jung CW, Kim BK, Lee YY. Int J Oncol. 2003;22:377-82. DOI: 10.3892/ijo.22.2.377.

[19] Park WH, Kim ES, Kim BK, Lee YY. Int J Oncol. 2003;23:197-204. DOI: 10.3892/ijo.23.1.197.

[20] Ketola K, Vainio P, Fey V, Kallioniemi O, Iljin K. Mol Cancer Therapeutics. 2010;9:3175-85. DOI: 10.1158/1535-7163.MCT-10-0368.

[21] Ketola K, Vuoristo A, Orešič M, Kallioniemi O, Iljin K. Monensin Induced Oxidative Stress Reduces Prostate Cancer Cell Migration and Cancer Stem Cell Population. Chapter 23 In: Oxidative Stress and Diseases. Lushchak V, editor. InTech; 2012: 521-40. ISBN: 9789535105527. DOI: 10.5772/34713.

[22] Kim SH, Kim KY, Yu SN, Park SG, Yu HS, Seo YK, et al. Anticancer Res. 2016;36:5835-43. DOI: 10.21873/anticanres.11168.

[23] Tyagi N, Ghosh PC. Eur J Pharm Sci. 2011;43:343-53. DOI: 10.1016/j.ejps.2011.05.010.

[24] Tyagi N, Rathore SS, Ghosh PC. Drug Deliv. 2011;18:394-404. DOI: 10.3109/10717544.2011.567309.

[25] Tyagi N, Rathore SS, Ghosh PC. Indian J Pharm Sci. 2013;75:16-22. DOI: 10.4103/0250-474X.113533.

[26] Yoon MJ, Kang YJ, Kim IY, Kim EH, Lee JA, Lim JH, et al. Carcinogenesis. 2013;34:1918-28. DOI: 10.1093/carcin/bgt137.

[27] Choi HS, Jeong EH, Lee TG, Kim SY, Kim HR, Kim CH. Tuberc Respir Dis. 2013;75:9-17. DOI: 10.4046/trd.2013.75.1.9.

[28] Tumova L, Pombinho AR, Vojtechova M, Stancikova J, Gradl D, Krausova M, et al. Mol Cancer Therapeutics. 2014;13:812-22. DOI: 10.1158/1535-7163.MCT-13-0625.

[29] Deng Y, Zhang J, Wang Z, Yan Z, Qiao M, Ye J, et al. Sci Rep. 2015;5:17523. DOI: 10.1038/srep17523.

[30] Verma SP, Das P, In Vitro Cell Develop Biol - Animal. 2018;54:736-42. DOI: 10.1007/s11626-018-0298-7.

[31] Wang X, Wu H, Zhang Z, Ma C, Wu T, et al. Sci Rep. 2018;8:17914. DOI: 10.1038/s41598-018-36214-5.

[32] Xin H, Li J, Zhang H, Li Y, Zeng S, Wang Z, et al. Peer J. 2019;7:e7354. DOI: 10.7717/peerj.7354.

[33] Vanneste M, Huang Q, Li M, Moose D, Zhao L, Stamnes MA, et al. Sci Rep. 2019;9:1200. DOI: $10.1038 / \mathrm{s} 41598-018-38019-\mathrm{y}$. 
[34] Pantcheva IN, Mitewa MI, Sheldrick WS, Oppel IM, Zhorova R, Dorkov P. Curr Drug Discov Technol. 2008;5:154-61. DOI: 10.2174/157016308784746247.

[35] Pantcheva IN, Zhorova R, Mitewa M, Simova S, Mayer-Figge H, Sheldrick WS. BioMetals. 2010;23:59-70. DOI: 10.1007/s10534-009-9269-5.

[36] Pantcheva IN, Ivanova J, Zhorova R, Mitewa M, Simova S, Mayer-Figge H, et al. Inorg Chim Acta. 2010;363:1879-86. DOI: 10.1016/j.ica.2010.02.009.

[37] Alexandrova RI, Zhivkova T, Alexandrov M, Miloshev G, Georgieva M, Pantcheva IN, et al. Centr Eur J Chem. 2012;10:1464-74. DOI: 10.2478/s11532-012-0071-9.

[38] Pantcheva IN, Alexandrova RI, Zhivkova T, Mitewa MI. Biotechn Biotechn Equipment. 2013;27:3703-8. DOI: 10.5504/BBEQ.2012.0088.

[39] Markowska A, Kaysiewicz J, Markowska J, Huczyński A. Bioorg Med Chem Lett. 2019;29:1549-54. DOI: 10.1016/j.bmcl.2019.04.045.

[40] Yusenko MV, Trentmann A, Andersson MK, Ghani LA, Jakobs A, Arteaga Paz MF, et al. Cancer Lett. 2020; pii: S0304-3835(20)30053-7. DOI: 10.1016/j.canlet.2020.01.039.

[41] Bugde P, Biswas R, Merien F, Lu J, Liu DX, Chen M, et al. Expert Opin Therapeutic Targets. 2017;21:511-30. DOI: 10.1080/14728222.2017.1310841.

[42] Heppner GH, Miller FR. Int Rev Cytol. 1998;177:1-56. DOI: 10.1016/S0074-7696(08)62230-5.

[43] Park WH, Lee MS, Park K, Kim ES, Kim BK, Lee YY. Int J Cancer. 2002;101:235-42. DOI: 10.1002/ijc. 10592 .

[44] Souza AC, Machado FS, Celes MRN, Faria G, Rocha LB, Silva JS, et al. J Vet Med A Physiol Pathol Clin Med. 2005;52:230-7. DOI: 10.1111/j.1439-0442.2005.00728.x.

[45] Klejborowska G, Jędrzejczyk M, Stępczyńska N, Maj E, Wietrzyk J, Huczyński A. Chem Biol Drug Des. 2019;94:1859-64. DOI: 10.1111/cbdd.13581. 